\title{
Accelerated aging test for forage pea seeds
}

\section{Teste de envelhecimento acelerado em sementes de ervilha forrageira}

\author{
Carla Gomes Machado'; Givanildo Zildo da Silva ${ }^{1 *}$; Silvia Sanielle Costa de \\ Oliveira $^{2}$; Cibele Chalita Martins ${ }^{3}$
}

\begin{abstract}
Forage pea is an important annual, cold climate crop with high levels of essential amino acids in its seeds, which are lacking in the composition of cereal grains. Therefore, livestock farmers use its seeds as a nutritious source of forage. To plant fields of this forage, it is necessary to know the quality of the seeds, determined through germination and vigor tests. In the literature, studies on vigor tests for forage pea seeds are scarce. This study aimed to verify the efficiency of vigor tests, with emphasis on accelerated aging to evaluate the physiological quality of forage pea seeds in order to select lots for seedling emergence in the field. Using accelerated aging tests, 10 lots of forage pea were evaluated for moisture content, thousand-seed weight, emergence percentage, emergence first count, speed index of seedlings in the field, germination, germination first count, and electrical conductivity. The following variations of methodology were used: temperatures of 41 and $42{ }^{\circ} \mathrm{C}$, exposure times of 48 and $72 \mathrm{~h}$, and different relative humidity values in the aging atmosphere, using distilled water $(100 \% \mathrm{RH})$, saturated solution of potassium chloride $(87 \% \mathrm{RH})$, and sodium chloride $(76 \% \mathrm{RH})$. The tests of germination, emergence first count of seedlings in the field, emergence speed index, and electrical conductivity are promising to evaluate the vigor of forage pea seed lots. The accelerated aging test conducted in a solution saturated with potassium chloride at $42{ }^{\circ} \mathrm{C}$ for $48 \mathrm{~h}$ is adequate to estimate the vigor of forage pea seed lots, providing information similar to that of the emergence of seedlings in the field.
\end{abstract}

Key words: Deterioration. Pisum sativum subsp. arvense. Vigor.

\section{Resumo}

A ervilha forrageira é uma importante cultura anual de clima frio, suas sementes contêm altos níveis de aminoácidos essenciais, que são carentes na composição de grãos de cereais, e por isso, são empregadas como fonte nutritiva de forragem por criadores de gado. Para implantação dos campos dessa forrageira é necessário o conhecimento da qualidade das sementes, pelo teste de germinação e os de vigor. $\mathrm{Na}$ literatura trabalhos sobre testes de vigor para sementes de ervilha forrageira são escassos. Este trabalho teve como objetivo verificar a eficiência de testes de vigor, com ênfase no envelhecimento acelerado para a avaliação da qualidade fisiológica de sementes de ervilha forrageira visando seleção de lotes para a emergência de plântulas em campo. Foram utilizados 10 lotes de ervilha forrageira e avaliados o grau de umidade, massa de mil sementes, porcentagem de emergência, primeira contagem de emergência e índice de velocidade de emergência de plântulas em campo, germinação, primeira contagem de

1 Profs. Drs., Programa de Pós-Graduação em Agronomia, Universidade Federal da Goiás, UFG/PPGA, Regional de Jataí, Jataí, GO, Brasil. E-mails: carlagomesmachado@gmail.com; givanildozildo@gmail.com

2 Prof $^{a}$ Dra $^{\mathrm{a}}$, Instituto Federal Goiano, IF Goiano, Campus Iporá, Iporá, GO, Brasil. E-mail: silvia.oliveira@ifgoiano.edu.br

3 Prof ${ }^{a}$ Dra $^{\mathrm{a}}$, Faculdade de Ciências Agrárias e Veterinárias, Universidade Estadual Paulista, UNESP, Jaboticabal, SP, Brasil. E-mail: cibele.chalita@unesp.br

* Author for correspondence 
germinação, condutividade elétrica e teste de envelhecimento acelerado com as seguintes variações de metodologia: temperaturas de 41 e $42{ }^{\circ} \mathrm{C}$; tempos de exposição de 48 e 72 horas e diferentes umidades na atmosfera de envelhecimento, mediante a utilização de água destilada (100\% UR), solução saturada de cloreto de potássio ( $87 \%$ UR) e cloreto de sódio ( $76 \%$ UR). Os testes germinação, primeira contagem de emergência de plântulas em campo, índice de velocidade de emergência e condutividade elétrica são promissores para avaliar o vigor de lotes de sementes de ervilha forrageira. $\mathrm{O}$ teste de envelhecimento acelerado conduzido em solução saturada com cloreto de potássio a $42{ }^{\circ} \mathrm{C}$ por 48 horas é adequado para estimar o vigor de lotes de sementes de ervilha forrageira, fornecendo informações semelhantes à emergência de plântulas em campo.

Palavras-chave: Deterioração. Pisum sativum subsp. arvense. vigor.

\section{Introduction}

Forage pea (Pisum sativum subsp. arvense L.) is an important annual, cold climate crop, and its seeds contain high levels of essential amino acids, such as lysine and tryptophan, which are absent in cereal grains (RODINO et al., 2009). This crop is highly resistant to cold weather conditions and is used to produce both hay and grain. Livestock farmers utilize forage pea as a source of high protein forage and forage additives (TAN et al., 2014). Because it is cultivated in the winter, when many agricultural areas remain unused in Brazil, 'BRS forage' has important characteristics as green manure and soil cover (TOMM et al., 2002; PINNOW et al., 2013; CARGNELUTTI FILHO et al., 2015). Compared to major crops and vegetables, the quality requirements, regulated by seed standards, are lower for commercial seeds of $P$. sativum subsp. arvense, because the technology of seed production, mainly with respect to plant breeding, is less developed in this species than in other species cultivated for a longer period (MACHADO et al., 2011). For planting fields of this forage, it is necessary to know the quality of the seeds, determined using germination and vigor tests. Studies on vigor tests for forage pea seeds are scarce, except for Machado et al. (2011) who determined the methodology for electrical conductivity test.

Therefore, research for the choice of efficient vigor tests to evaluate lots of seeds of a particular species that could be adopted in the quality control of companies is considered priority (MARCOS FILHO, 2015a). These studies should be conducted using as many lots as possible, to increase the representativeness and reliability in the results obtained (MARCOS FILHO, 2015a, 2015b).

Vigor tests identify differences in the physiological quality of seed lots, especially those with similar germination time, and can estimate their capacity for storage and emergence of seedlings in the field. Therefore, these tests aim to identify the lots that will have better performance in the field or during storage. This type of information can help seed-producing companies to make informed decisions with respect to the destination of the lot, marketing region or the convenience of either storing or selling the seed (MARCOS FILHO, 2015a).

The introduction and use of the accelerated aging test in Brazil occurred close to its development in the United States of America. The significant increase in research on the topic and its increased use over time, have made the test one of the most used in Brazil (MARCOS FILHO, 2015) to evaluate the vigor of seeds in species such as corn (MARCOS FILHO, 2015a), forage radish (OLIVEIRA et al., 2014) and black oats (SOUZA et al., 2009). This test establishes that the rate of deterioration is accelerated when seeds are exposed to high temperature and relative humidity, preponderant factors in the intensity and speed of deterioration.

The accelerated aging test consists of subjecting seeds to adverse conditions of high temperature $\left(40-45{ }^{\circ} \mathrm{C}\right.$ ) and relative humidity (between 95\% and $100 \%$ for traditional accelerated aging, and 76 $\%$ for accelerated aging with a saturated solution 
of sodium chloride), for a certain period and then observing the response through the standard test of germination (MARCOS FILHO, 2015b; JIANHUA; MCDONALD, 1996). In the traditional accelerated aging test, the differences in water absorption by seeds exposed to high relative humidity can cause accentuated variations in their moisture content. Accelerated aging with a saturated solution is used as an alternative in studies of small-seeded species, by using lower relative humidity than that used in the traditional accelerated aging test. The low relative humidity in the air prevents the growth of microorganisms, minimizing the effects of pathogens associated with seeds in the traditional accelerated aging test (JIANHUA; McDONALD, 1996).

This study aimed to verify the efficiency of vigor tests, with emphasis on the accelerated aging test to evaluate the physiological quality of forage pea seeds in order to select lots for emergence of seedlings in the field.

\section{Materials and Methods}

This study was carried out at the Laboratory of Seed Analysis of the Plant Science Department at the Faculty of Agronomic Sciences, São Paulo State University, "Júlio de Mesquita Filho" - FCA/ UNESP. Ten lots of forage pea seeds were used, provided by the Agronomic Institute of Paraná - IAPAR, Londrina-PR. The recently harvested samples were homogenized and then placed in Kraft paper bags, in an air-conditioned environment at $5{ }^{\circ} \mathrm{C}$.

For comparing and differentiating the physiological quality of the lots, the seeds were subjected to the following determinations and evaluations:

Moisture content: determined before and after the accelerated aging tests, using two subsamples of 20 seeds from each lot, by the oven method at $105 \pm$ $3{ }^{\circ} \mathrm{C}$ for $24 \mathrm{~h}$ (BRASIL, 2009).
Thousand-seed weight: determined using eight subsamples of 100 seeds per lot (BRASIL, 2009).

Emergence of seedlings in the field: conducted in a protected environment (screened), with plots consisting of two furrows of $1.5 \mathrm{~m}$, spaced by 0.2 $\mathrm{m}$, sowing 50 seeds per furrow at $4-5 \mathrm{~cm}$ depth. The counts were performed daily until 14 days after sowing, when the percentage of seedling emergence in the field was calculated according to Nakagawa (1994). Emergence first count of seedlings in the field: emerged seedlings were counted when they represented $50 \pm 1 \%$ of the final emergence (MACHADO et al., 2019). Emergence speed index of seedlings in the field: calculated from the data of daily counts of emerged seedlings in the emergence test and determined using the formula proposed by Maguire (1962).

Germination: conducted on a paper roll substrate, moistened with a water volume equivalent to 2.5 times the weight of the dry substrate, and placed in a biochemical oxygen demand germination chamber at $20{ }^{\circ} \mathrm{C}$. The percentage of normal and abnormal seedlings was determined on the seventh day after sowing (MACHADO et al., 2019). To maintain substrate moisture, the rolls with the seeds were placed in plastic bags (COIMBRA et al. 2007). Germination first count: was carried out along with the germination test, from the first count to the fourth day after sowing (MACHADO et al., 2019).

Electrical conductivity: 50 seeds were soaked in $250 \mathrm{~mL}$ distilled water (conductivity lower than 5 $\mu \mathrm{S} \mathrm{cm}^{-1}$ ) at $25^{\circ} \mathrm{C}$ for $24 \mathrm{~h}$ (MACHADO et al., 2011; VIEIRA; KRZYZANOWSKI, 1999). The electrical conductivity of the solution was determined using a conductivity meter and the results were expressed in $\mu \mathrm{S} \mathrm{cm}^{-1} \mathrm{~g}^{-1}$ (VIEIRA; KRZYZANOWSKI, 1999).

Methodologies of the accelerated aging test: three different values of relative humidity $(\mathrm{RH})$ were evaluated over 48 and 72 h: $100 \%$ RH, obtained using $40 \mathrm{~mL}$ of distilled water (McDONALD; PHANEENDRANATH, 1978); 87 \% RH, obtained using $40 \mathrm{~mL}$ of saturated potassium chloride (32 
$\mathrm{g} \mathrm{KCl} / 100 \mathrm{~mL}$ of distilled water); and $76 \% \mathrm{RH}$, obtained using $40 \mathrm{~mL}$ of saturated sodium chloride (40 $\mathrm{g} \mathrm{NaCl} / 100 \mathrm{~mL}$ of distilled water). For each treatment and lot, 220 seeds were used, distributed in a single layer on an aluminum mesh, and placed in plastic boxes $(11.0 \times 11.0 \times 3.5 \mathrm{~cm})$ that are specifically used for accelerated aging testing (McDONALD; PHANEENDRANATH, 1978). At the bottom of each plastic box, distilled water or saturated solution was added and the closed boxes were wrapped in plastic bags and kept at 41 and 42 ${ }^{\circ} \mathrm{C}$ for the pre-established exposure periods. After each treatment, seed vigor was determined using the germination test, with counts on the fourth day, and seed moisture content was determined.

The experimental design was completely randomized, and the means were compared using Scott-Knott test at a $5 \%$ probability level.
Means obtained with accelerated aging in water, kept for $72 \mathrm{~h}$ at $42{ }^{\circ} \mathrm{C}$, were transformed to ( $\mathrm{x}+$ $0.5)^{1 / 2}$ (FERREIRA, 2000). By using Pearson's method, the data obtained for the treatments of aging methodologies were correlated with the data of first count, germination percentage, electrical conductivity, and emergence of seedlings in the field.

\section{Results and Discussion}

The initial moisture content of the lots of $P$. sativum subsp. arvense seeds showed low variation, from $14.0 \%$ to $14.6 \%$ (Table 1 ). These values are within the range of variation of two percentage points, which gives reliability to the test results (MARCOS FILHO, 2015b).

Table 1. Moisture content (MC), thousand-seed weight (TSW), emergence (E), emergence first count (EFC) and emergence speed index of seedlings in the field (ESI), germination (G), germination first count (GFC), and electrical conductivity (EC) of 10 lots of forage pea seeds.

\begin{tabular}{ccccccccc}
\hline Lots & MC & TSW & E & EFC & ESI & G & GFC & EC \\
\hline & $----\%---$ & $-----g-----$ & $---------0 \%--------$ & & $---------\%=------$ & $\mu \mathrm{S} \mathrm{cm}^{-1} \mathrm{~g}^{-1}$ \\
\hline 1 & 14.1 & $149.04 \mathrm{a}$ & $94 \mathrm{a}$ & $64 \mathrm{c}$ & $15.84 \mathrm{a}$ & $97 \mathrm{a}$ & $47 \mathrm{c}$ & $18.18 \mathrm{~b}$ \\
2 & 14.3 & $146.50 \mathrm{~b}$ & $93 \mathrm{a}$ & $65 \mathrm{c}$ & $14.79 \mathrm{~b}$ & $100 \mathrm{a}$ & $42 \mathrm{~d}$ & $18.67 \mathrm{~b}$ \\
3 & 14.0 & $150.24 \mathrm{a}$ & $86 \mathrm{~b}$ & $61 \mathrm{c}$ & $14.74 \mathrm{~b}$ & $98 \mathrm{a}$ & $56 \mathrm{~b}$ & $12.94 \mathrm{a}$ \\
4 & 14.1 & $144.40 \mathrm{c}$ & $87 \mathrm{~b}$ & $71 \mathrm{~b}$ & $15.80 \mathrm{a}$ & $94 \mathrm{~b}$ & $66 \mathrm{a}$ & $18.15 \mathrm{~b}$ \\
5 & 14.4 & $150.04 \mathrm{a}$ & $89 \mathrm{~b}$ & $78 \mathrm{a}$ & $16.04 \mathrm{a}$ & $92 \mathrm{~b}$ & $32 \mathrm{e}$ & $16.79 \mathrm{~b}$ \\
6 & 14.1 & $107.44 \mathrm{f}$ & $88 \mathrm{~b}$ & $55 \mathrm{~d}$ & $14.85 \mathrm{~b}$ & $95 \mathrm{~b}$ & $42 \mathrm{~d}$ & $21.24 \mathrm{c}$ \\
7 & 14.6 & $96.03 \mathrm{~g}$ & $86 \mathrm{~b}$ & $68 \mathrm{c}$ & $14.94 \mathrm{~b}$ & $85 \mathrm{c}$ & $45 \mathrm{c}$ & $23.87 \mathrm{c}$ \\
8 & 14.0 & $94.04 \mathrm{~h}$ & $80 \mathrm{c}$ & $54 \mathrm{~d}$ & $13.17 \mathrm{c}$ & $76 \mathrm{~d}$ & $44 \mathrm{c}$ & $28.41 \mathrm{~d}$ \\
9 & 14.2 & $136.66 \mathrm{~d}$ & $82 \mathrm{c}$ & $63 \mathrm{c}$ & $13.87 \mathrm{~b}$ & $84 \mathrm{c}$ & $31 \mathrm{e}$ & $28.02 \mathrm{~d}$ \\
10 & 14.2 & $133.13 \mathrm{e}$ & $68 \mathrm{~d}$ & $38 \mathrm{e}$ & $11.06 \mathrm{~d}$ & $75 \mathrm{~d}$ & $38 \mathrm{~d}$ & $38.71 \mathrm{e}$ \\
\hline $\mathrm{CV}(\%)$ & 1.97 & 0.95 & 4.03 & 5.67 & 4.48 & 2.80 & 7.33 & 15.00 \\
\hline
\end{tabular}

* Means followed by different letters in the column differ by Scott-Knott test at $5 \%$ probability level. CV=Coefficient of Variation.

For the results of thousand-seed weight, it was observed that the seeds of lots 1,3 , and 5 had higher weights than those of the other lots. Larger and denser seeds normally have well-formed embryos and larger amounts of reserves, potentially making them more vigorous (CARVALHO; NAKAGAWA, 2012).

Seedling emergence in the field was used as a reference for the selection of vigor tests (MELO et al., 2017; SILVA et al., 2017), and it was possible to 
classify the performance of the lots in descending order of vigor from 1 to 10 and group them into four classes of vigor: high (lots 1 and 2), high-medium (lots from 3 to 7), low-medium (lots 8 and 9), and low (lot 10). This criterion was used because one purpose of the vigor tests is to evaluate the physiological quality of the seeds to differentiate the lots in terms of vigor level and predict seedling emergence in the field (COIMBRA et al., 2007; MARCOS FILHO, 2015a; OLIVEIRA et al., 2014; MELO et al., 2017; SILVA et al., 2017).

Similarly, the emergence first count of seedlings in the field, carried out on the sixth day after sowing when the final seedling emergence was more than $50 \%$, and the emergence speed index of seedlings in the field were used to group the lots into five and four classes of vigor, respectively. These tests indirectly evaluate the germination speed of the seeds, which is a desired characteristic in the establishment of forage species (PARIZ et al., 2010; SILVA et al., 2017).

For most of the evaluated lots, the vigor classes were similar when evaluated on the basis of germination test and percentage of seedling emergence in the field. The results of the germination test allowed the lots to be ranked in four classes of vigor: high (lots from 1 to 3 ), highmedium (lots from 4 to 6), low-medium (lots 7 and 9), and low (lots 8 and 10). Similarly, Silva et al. (2017) observed efficiency of the germination test in evaluating the quality of 10 lots of seeds of the forage grass Brachiaria brizantha.

The test of germination first count, despite ranking the lots into vigor classes, produced unreliable results because the results conflicted with those obtained in the other tests as well as the reference test, emergence of seedlings in the field.
The electrical conductivity test classified the performance of the lots and grouped them into five vigor classes: high (lot 3), high-medium (lots 1, 2, 4, and 5), medium (lots 6 and 7), low-medium (lots 8 and 9), and low (lot 10). The efficiency of this test was also verified by Machado et al. (2011), who evaluated the vigor of 10 lots of forage pea seeds. The same authors reported that the use of the electrical conductivity test (using $250 \mathrm{~mL}$ of water, at $25^{\circ} \mathrm{C}$ for $24 \mathrm{~h}$ ) as routine evaluation of $P$. sativum subsp. arvense seeds, which differ from the common pea seeds with respect to the seed coat (thickness and color), is a promising method to differentiate lots of this species. This was corroborated in the present study.

In the determination of the moisture contents of the 10 lots of forage pea seeds (Table 2), after the accelerated aging tests, only the seeds kept in water at $41{ }^{\circ} \mathrm{C}$ for $48 \mathrm{~h}$ showed variation greater than 4 $\%$, which is outside the tolerance range of $3-4 \%$, as an indication that the accelerated aging test was conducted properly (MARCOS FILHO, 2015b). It is worth pointing out that greater variation may occur in small seeds (MARCOS FILHO, 2015a; 2015b), such as those of forage pea.

The modified accelerated aging test reduced water absorption by seeds, leading to less drastic effects than those caused by traditional aging in relation to the process of seed deterioration. Similar effects for pea seeds were reported by Nascimento et al. (2007). The less drastic effect on the quality of forage pea seeds can be observed in the test with potassium chloride at $42{ }^{\circ} \mathrm{C}$ for 48 and $72 \mathrm{~h}$ and in the test with sodium chloride at $41{ }^{\circ} \mathrm{C}$ for $72 \mathrm{~h}$, which showed a positive correlation with the emergence of seedlings in the field (Table 3). 
Table 2. Moisture content (\%) after accelerated aging (AA) in water (100\% RH), in saturated solution of potassium chloride $(87 \% \mathrm{RH})$, and sodium chloride $(76 \% \mathrm{RH})$ of 10 lots of forage pea seeds after two conditioning periods (48 and $72 \mathrm{~h}$ ) at temperatures of 41 and $42{ }^{\circ} \mathrm{C}$.

\begin{tabular}{|c|c|c|c|c|c|c|c|c|c|c|c|c|}
\hline \multirow[t]{3}{*}{ Lots } & \multicolumn{4}{|c|}{ AA in water } & \multicolumn{4}{|c|}{ AA in solution of potassium chloride } & \multicolumn{4}{|c|}{ AA in solution of sodium chloride } \\
\hline & \multicolumn{2}{|c|}{$41^{\circ} \mathrm{C}$} & \multicolumn{2}{|c|}{$42^{\circ} \mathrm{C}$} & \multicolumn{2}{|c|}{$41^{\circ} \mathrm{C}$} & \multicolumn{2}{|c|}{$42^{\circ} \mathrm{C}$} & \multicolumn{2}{|c|}{$41^{\circ} \mathrm{C}$} & \multicolumn{2}{|c|}{$42{ }^{\circ} \mathrm{C}$} \\
\hline & $48 \mathrm{~h}$ & $72 \mathrm{~h}$ & $48 \mathrm{~h}$ & $72 \mathrm{~h}$ & $48 \mathrm{~h}$ & $72 \mathrm{~h}$ & $48 \mathrm{~h}$ & $72 \mathrm{~h}$ & $48 \mathrm{~h}$ & $72 \mathrm{~h}$ & $48 \mathrm{~h}$ & $72 \mathrm{~h}$ \\
\hline 1 & 32.5 & 33.3 & 35.1 & 33.1 & 14.5 & 17.8 & 17.1 & 17.3 & 15.5 & 14.0 & 14.3 & 14.2 \\
\hline 2 & 38.5 & 34.4 & 35.0 & 33.0 & 14.2 & 17.1 & 17.5 & 17.4 & 13.2 & 14.2 & 16.1 & 14.0 \\
\hline 3 & 30.1 & 34.4 & 33.0 & 33.0 & 14.5 & 19.1 & 17.8 & 17.0 & 14.5 & 13.9 & 14.3 & 15.5 \\
\hline 4 & 33.0 & 33.1 & 30.1 & 33.2 & 14.2 & 17.4 & 17.5 & 17.2 & 14.2 & 14.2 & 13.4 & 15.9 \\
\hline 5 & 37.1 & 34.2 & 33.2 & 33.1 & 13.1 & 17.0 & 18.8 & 17.2 & 14.2 & 13.8 & 15.6 & 14.4 \\
\hline 6 & 38.1 & 35.1 & 34.2 & 33.5 & 14.4 & 16.4 & 18.1 & 17.5 & 14.4 & 14.0 & 15.6 & 15.9 \\
\hline 7 & 38.7 & 35.3 & 34.5 & 33.5 & 13.3 & 17.5 & 18.7 & 17.0 & 15.6 & 13.1 & 14.8 & 14.0 \\
\hline 8 & 34.0 & 34.0 & 33.0 & 33.8 & 14.3 & 17.0 & 17.1 & 18.5 & 14.3 & 13.9 & 14.4 & 14.3 \\
\hline 9 & 39.1 & 35.2 & 35.2 & 33.5 & 14.2 & 16.2 & 18.7 & 17.3 & 15.2 & 14.2 & 14.4 & 15.8 \\
\hline 10 & 35.5 & 35.0 & 33.0 & 34.3 & 14.3 & 17.9 & 18.5 & 16.1 & 14.3 & 13.8 & 16.1 & 15.7 \\
\hline
\end{tabular}

Table 3. Pearson's coefficient of correlation ( $\mathrm{r}$ ) between the results of laboratory tests with the emergence of seedlings in the field for 10 lots of forage pea seeds.

\begin{tabular}{|c|c|c|c|}
\hline \multicolumn{3}{|c|}{ Laboratory tests X Emergence of seedlings in the field } & \multirow{2}{*}{$\frac{\mathrm{r}}{0.25^{\text {ns }}}$} \\
\hline Thousand-seed weight & & & \\
\hline Germination & & & $0.77 * *$ \\
\hline Germination first count & & & $0.23^{\mathrm{ns}}$ \\
\hline Emergence first count of seedlings in the field & & & $0.63 * *$ \\
\hline Emergence speed index of seedlings in the field & & & $0.88^{* *}$ \\
\hline Electrical conductivity & & & $-0.74 * *$ \\
\hline \multirow{4}{*}{ Accelerated aging in water $(100 \% \mathrm{RH})$} & \multirow{2}{*}{$41^{\circ} \mathrm{C}$} & $48 \mathrm{~h}$ & $0.72 * *$ \\
\hline & & $72 \mathrm{~h}$ & $0.47 * *$ \\
\hline & \multirow{2}{*}{$42{ }^{\circ} \mathrm{C}$} & $48 \mathrm{~h}$ & $0.30 *$ \\
\hline & & $72 \mathrm{~h}$ & $0.43 * *$ \\
\hline \multirow{4}{*}{$\begin{array}{l}\text { Accelerated aging in saturated solution of potassium } \\
\text { chloride }(87 \% \mathrm{RH})\end{array}$} & \multirow{2}{*}{$41{ }^{\circ} \mathrm{C}$} & $48 \mathrm{~h}$ & $0.50 * *$ \\
\hline & & $72 \mathrm{~h}$ & $0.59 * *$ \\
\hline & \multirow{2}{*}{$42^{\circ} \mathrm{C}$} & $48 \mathrm{~h}$ & $0.70 * *$ \\
\hline & & $72 \mathrm{~h}$ & $0.69 * *$ \\
\hline \multirow{4}{*}{$\begin{array}{l}\text { Accelerated aging in saturated solution of sodium } \\
\text { chloride }(76 \% \mathrm{RH})\end{array}$} & \multirow{2}{*}{$41{ }^{\circ} \mathrm{C}$} & $48 \mathrm{~h}$ & $0.39 * *$ \\
\hline & & $72 \mathrm{~h}$ & $0.72 * *$ \\
\hline & \multirow{2}{*}{$42{ }^{\circ} \mathrm{C}$} & $48 \mathrm{~h}$ & $0.47 * *$ \\
\hline & & $72 \mathrm{~h}$ & $0.47 * *$ \\
\hline
\end{tabular}

ns,$*$, and **: not significant, significant at $1 \%$ and $5 \%$ probability levels by $\mathrm{F}$ test, respectively.

Although moisture content is a widely used indicator to evaluate the efficiency of the accelerated aging test, variations slightly above the suggested values have been reported in studies of validation of methodologies for this test (RAMOS et al., 2004), without compromising the results. This fact 
is corroborated by the positive correlation with the emergence of seedlings in the field for seeds aged in water at $41^{\circ} \mathrm{C}$ for $48 \mathrm{~h}$.

According to Figueiredo Filho and Silva Júnior (2009), a correlation between 0.40 and 0.60 can be considered moderate and, above this value, strong. Given this classification, among the methods of accelerated aging, the most reliable results to evaluate the quality of seed lots were obtained using potassium chloride at $42{ }^{\circ} \mathrm{C}$ for 48 and $72 \mathrm{~h}$ and sodium chloride at $41^{\circ} \mathrm{C}$ for $72 \mathrm{~h}$, since they were highly correlated with seedling emergence in the field, with values of $0.70 \%, 0.69 \%$, and $0.72 \%$, respectively.

The correlation of data from a vigor test with the emergence of seedlings in the field is crucial to consider the test as efficient because, in addition to classifying lots into different vigor classes, it should be as close as possible to emergence of seedlings in the field (LOPES; FRANKE, 2010; MARCOS FILHO, 2015a; MELO et al., 2017; SILVA et al., 2017).

All temperatures, times, and levels of relative humidity ranked the lots of forage pea seeds into vigor classes, except for $42{ }^{\circ} \mathrm{C}$ with exposure period of $72 \mathrm{~h}$ in water (Table 4). This methodology of conducting the test caused a drastic reduction in the germination percentage and did not deliver results consistent with those of the reference test (Tables 1 and 3$)$.

According to Santos et al. (2004), from 72 h of artificial aging, there is a reduction in the activity of the acid phosphatase and esterase enzymes. These alterations in the enzymatic activity of seeds may cause reduction of germination in response to aging. Moreover, according to Marcos Filho (2015a), temperatures above $41^{\circ} \mathrm{C}$, instead of causing stress, may lead to denaturation of the protein and death of the seeds, depending on the species and time of exposure; therefore, the use of temperatures between 43 and $45{ }^{\circ} \mathrm{C}$ usually cause complete metabolic inactivation.

It should be emphasized that the tests of interest in the evaluation of lots in seed analysis laboratories, besides ranking the lots into vigor classes, need to generate results correlated with the emergence of seedlings in the field (MARCOS FILHO, 2015a). Therefore, among the aging methods, the ones that were correlated with the reference test were those conducted in water at $41{ }^{\circ} \mathrm{C}$ for $48 \mathrm{~h}$, in potassium chloride at $42{ }^{\circ} \mathrm{C}$ for 48 and $72 \mathrm{~h}$ and in sodium chloride at $41{ }^{\circ} \mathrm{C}$ for $72 \mathrm{~h}$ (Table 3). Among these, conditioning in water is not recommended, because it leads to large variation in water content (Table 2). Therefore, it is not necessary to discuss the methods with no correlation.

For the accelerated aging test with saturated solution of potassium chloride at $42{ }^{\circ} \mathrm{C}$ for $48 \mathrm{~h}$ (Table 4), the lots were ranked and grouped into four vigor classes: high (lots from 1 to 3 ), highmedium (lots from 4 to 8), low-medium (lot 9), and low (lot 10). The results of this method were similar to those observed in the emergence of seedlings in the field, in $80 \%$, that is, eight of the 10 lots with similar rank, because it ranked lot 3 as high vigor and lot 8 as high-medium vigor. Therefore, this test can be considered promising for the quality control of forage pea seeds.

According to Jianhua and McDonald (1996), in the accelerated aging test with a saturated salt solution, despite the low water content, there is enough stress to reduce germination, and hence, rank lots into levels of quality. The use of a saturated solution also solves the problem associated with small seeds, such as those of the studied species, which absorb water more rapidly, resulting in a large variation in seed water content and lack of uniformity between seed samples (MARCOS FILHO, 2015a; 2015b). 
Table 4. Germination percentage after accelerated aging (AA) with water (100\% RH), saturated saline solution of potassium chloride $(87 \% \mathrm{RH})$ and sodium chloride $(76 \% \mathrm{RH})$ of 10 lots of forage pea seeds, after two conditioning periods ( 48 and $72 \mathrm{~h}$ ) at temperatures of 41 and $42{ }^{\circ} \mathrm{C}$.

\begin{tabular}{|c|c|c|c|c|c|}
\hline \multirow{2}{*}{ EA } & \multirow{2}{*}{ Lots } & \multicolumn{2}{|c|}{$41^{\circ} \mathrm{C}$} & \multicolumn{2}{|c|}{$42^{\circ} \mathrm{C}$} \\
\hline & & $48 \mathrm{~h}$ & $72 \mathrm{~h}$ & $48 \mathrm{~h}$ & $72 \mathrm{~h}^{1}$ \\
\hline \multirow{10}{*}{$\begin{array}{l}\text { Water } \\
\left(\mathrm{H}_{2} \mathrm{O}\right)\end{array}$} & 1 & $85 \mathrm{a}$ & $56 \mathrm{~b}$ & $28 \mathrm{c}$ & $3 \mathrm{a}$ \\
\hline & 2 & $78 \mathrm{~b}$ & $53 \mathrm{~b}$ & $37 \mathrm{~b}$ & $3 a$ \\
\hline & 3 & $84 \mathrm{a}$ & $69 \mathrm{a}$ & $62 \mathrm{a}$ & $4 \mathrm{a}$ \\
\hline & 4 & $69 \mathrm{~b}$ & $35 \mathrm{c}$ & $25 \mathrm{c}$ & $3 \mathrm{a}$ \\
\hline & 5 & $77 \mathrm{~b}$ & $46 \mathrm{~b}$ & $32 \mathrm{~b}$ & $2 a$ \\
\hline & 6 & $64 \mathrm{c}$ & $21 \mathrm{~d}$ & $24 \mathrm{c}$ & $3 \mathrm{a}$ \\
\hline & 7 & $60 \mathrm{c}$ & $20 \mathrm{~d}$ & $26 \mathrm{c}$ & $2 a$ \\
\hline & 8 & $54 \mathrm{c}$ & $20 \mathrm{~d}$ & $10 \mathrm{~d}$ & $1 \mathrm{a}$ \\
\hline & 9 & $58 \mathrm{c}$ & $31 \mathrm{c}$ & $24 \mathrm{c}$ & $2 a$ \\
\hline & 10 & $43 \mathrm{~d}$ & $22 \mathrm{~d}$ & $21 \mathrm{c}$ & $2 \mathrm{a}$ \\
\hline \multirow{10}{*}{$\begin{array}{l}\text { Potassium chloride } \\
\qquad(\mathrm{KCl})\end{array}$} & 1 & $71 \mathrm{~b}$ & $75 \mathrm{~b}$ & $81 \mathrm{a}$ & $72 \mathrm{a}$ \\
\hline & 2 & $82 \mathrm{a}$ & $81 \mathrm{a}$ & $80 \mathrm{a}$ & $64 \mathrm{~b}$ \\
\hline & 3 & $75 \mathrm{~b}$ & $86 \mathrm{a}$ & $86 \mathrm{a}$ & $78 \mathrm{a}$ \\
\hline & 4 & $68 \mathrm{~b}$ & $71 \mathrm{~b}$ & $72 b$ & $77 \mathrm{a}$ \\
\hline & 5 & $86 \mathrm{a}$ & $76 \mathrm{~b}$ & $73 \mathrm{~b}$ & $64 \mathrm{~b}$ \\
\hline & 6 & $69 \mathrm{~b}$ & $72 b$ & $75 \mathrm{~b}$ & $68 \mathrm{a}$ \\
\hline & 7 & $77 \mathrm{~b}$ & $76 \mathrm{~b}$ & $73 \mathrm{~b}$ & $69 \mathrm{a}$ \\
\hline & 8 & $74 \mathrm{~b}$ & $69 \mathrm{~b}$ & $69 \mathrm{~b}$ & $54 \mathrm{~b}$ \\
\hline & 9 & $53 \mathrm{c}$ & $52 \mathrm{c}$ & $64 \mathrm{c}$ & $39 c$ \\
\hline & 10 & $55 \mathrm{c}$ & $51 \mathrm{c}$ & $47 \mathrm{~d}$ & $24 \mathrm{~d}$ \\
\hline \multirow{10}{*}{$\begin{array}{l}\text { Sodium chloride } \\
\qquad(\mathrm{NaCl})\end{array}$} & 1 & $80 \mathrm{a}$ & $61 \mathrm{~b}$ & $73 \mathrm{a}$ & $51 \mathrm{~b}$ \\
\hline & 2 & $83 \mathrm{a}$ & $69 \mathrm{a}$ & $76 \mathrm{a}$ & $71 \mathrm{a}$ \\
\hline & 3 & $82 \mathrm{a}$ & $81 \mathrm{a}$ & $80 \mathrm{a}$ & $63 \mathrm{a}$ \\
\hline & 4 & $76 \mathrm{a}$ & $54 \mathrm{~b}$ & $68 \mathrm{a}$ & $57 \mathrm{~b}$ \\
\hline & 5 & $83 \mathrm{a}$ & $71 \mathrm{a}$ & $77 \mathrm{a}$ & $69 \mathrm{a}$ \\
\hline & 6 & $76 \mathrm{a}$ & $58 \mathrm{~b}$ & $68 \mathrm{a}$ & $59 \mathrm{~b}$ \\
\hline & 7 & $75 \mathrm{a}$ & $75 \mathrm{a}$ & $64 \mathrm{a}$ & $70 \mathrm{a}$ \\
\hline & 8 & $67 \mathrm{~b}$ & $63 \mathrm{~b}$ & $76 \mathrm{a}$ & $55 \mathrm{~b}$ \\
\hline & 9 & $71 \mathrm{a}$ & $68 \mathrm{a}$ & $55 \mathrm{~b}$ & $59 \mathrm{~b}$ \\
\hline & 10 & $54 \mathrm{c}$ & $46 \mathrm{c}$ & $43 \mathrm{~b}$ & $38 \mathrm{c}$ \\
\hline \multirow{3}{*}{\multicolumn{2}{|c|}{$\begin{array}{l}\mathrm{CV}_{\mathrm{H} 2 \mathrm{O}}(\%) \\
\mathrm{CV}_{\mathrm{KCl}}(\%) \\
\mathrm{CV}_{\mathrm{NaCl}}(\%)\end{array}$}} & 10.09 & 22.3 & 20.15 & 16.61 \\
\hline & & 8.42 & 10.07 & 8.93 & 13.35 \\
\hline & & 10.81 & 11.34 & 16.15 & 16.65 \\
\hline
\end{tabular}

* Means followed by different letters in the column differ by Scott-Knott test at 5\% probability level. 1Means obtained with accelerated aging in water conditioned for $72 \mathrm{~h}$ at $42{ }^{\circ} \mathrm{C}$ were transformed to $(\mathrm{x}+0.5)^{1 / 2}$. $\mathrm{CV}=\mathrm{Coefficient}$ of Variation.

When aging was carried out in a saturated solution of potassium chloride at $42{ }^{\circ} \mathrm{C}$ for $72 \mathrm{~h}$, the lots were ranked and grouped into four vigor classes: high (lots 1, 3, 4, 6, and 7), high-medium (lots 2, 4, and 8), low-medium (lot 9), and low (lot $10)$. However, there was only $40 \%$ similarity with the ranking by emergence of seedlings in the field.
For the classification of the lots after aging in sodium chloride at $41{ }^{\circ} \mathrm{C}$ for $72 \mathrm{~h}$, the lots were grouped into three vigor classes: high (lots 2, 3, 5, 7, and 9), medium (lots 1, 4, 6, and 8), and low (lot 10). However, there was only $40 \%$ similarity with the ranking by emergence of seedlings in the field. These results diverge from the results of Nascimento 
et al. (2007), who classified the aging test with and without the use of saturated salt solution $(\mathrm{NaCl})$ at $41{ }^{\circ} \mathrm{C}$ for $48 \mathrm{~h}$ as efficient in the evaluation of the vigor of pea seeds.

The tests of germination, first count and emergence speed index of seedlings in the field, electrical conductivity, and accelerated aging conducted in water at $41{ }^{\circ} \mathrm{C}$ for $48 \mathrm{~h}$, potassium chloride at $42{ }^{\circ} \mathrm{C}$ for 48 and $72 \mathrm{~h}$, and sodium chloride at $41^{\circ} \mathrm{C}$ for $72 \mathrm{~h}$ show promise as methods to evaluate the vigor of lots of forage pea seeds. It is worth pointing out that in the method conducted using potassium chloride at $42{ }^{\circ} \mathrm{C}$ for $48 \mathrm{~h}$, there was a high similarity and high correlation with the emergence of seedlings in the field.

\section{Conclusions}

The tests of germination, first count and emergence speed index of seedlings in the field, and electrical conductivity in the laboratory are promising to evaluate the vigor of lots of forage pea seeds.

The accelerated aging test conducted in saturated potassium chloride solution at $42{ }^{\circ} \mathrm{C}$ for $48 \mathrm{~h}$ is adequate to estimate the vigor of lots of forage pea seeds, providing information similar to that obtained in the emergence of seedlings in the field.

\section{References}

BRASIL. Ministério da Agricultura e da Reforma Agrária. Regras para análise de sementes. Brasília, DF: MAPA, 2009. 395 p.

CARGNELUTTI FILHO, A.; ALVES, B. M.; BURIN, C.; KLEINPAUL, J. A.; NEU, I. M. M.; SILVEIRA, D. L.; SIMÕES, F. M.; SPANHOLI, R.; MEDEIROS, L. B. Tamanho de parcela e número de repetições em ervilha forrageira. Ciência Rural, Santa Maria, v. 45, n. 7, p. 1174-1182, 2015. DOI: 10.1590/0103-8478cr20141043

CARVALHO, N. M.; NAKAGAWA, J. Sementes: ciência, tecnologia e produção. 5. ed. Jaboticabal: FUNEP, 2012. 590 p.
COIMBRA, R. A. TOMAZ, C. D. A.; MARTINS, C. C.; NAKAGAWA, J. Teste de germinação com acondicionamento dos rolos de papel em sacos plásticos visando a otimização dos resultados. Revista Brasileira Sementes, Londrina, v. 29, n. 1, p. 92-97, 2007. DOI: 10.1590/S0101-31222007000100013

FERREIRA, P. V. Estatística experimental aplicada à agronomia. 3. ed. Maceió: EDUFAL, 2000. 422 p.

FIGUEIREDO FILHO, D. B.; SILVA JÚNIOR, J. A. Desvendando os mistérios do coeficiente de correlação de Pearson (r). Revista Política Hoje, Recife, v. 18, n. 1, p. 115-46, 2009.

JIANHUA, Z.; McDONALD, M. B. The saturated salt accelerated aging test for small-seeded crops. Seed Science and Technology, Switzerland, v. 25, n. 1, p. 123131, 1996.

LOPES, R. R.; FRANKE, L. B. Teste de condutividade elétrica para avaliação da qualidade fisiológica de sementes de azevém (Lolium multiflorum L.). Revista Brasileira de Sementes, Londrina, v. 32, n. 1, p. 123-130, 2010. DOI: $10.1590 / \mathrm{S} 0101-31222010000100014$

MACHADO, C. G.; MARTINS, C. C.; SANTANA, D. G.; CRUZ, S. C. S.; OLIVEIRA, S. S. C. Adequação do teste de condutividade elétrica para sementes de Pisum sativum subsp. Arvense. Ciência Rural, Santa Maria, v. 41, n. 6, p. 988-995, 2011. DOI: 10.1590/S010384782011005000062

MACHADO, C. G.; MARTINS, C. C.; SILVA, G. Z.; CRUZ, S. C. S.; ASSIS, R. M. Adequacy of methodology for conducting germination test in forage pea seeds. Bioscience Journal, Uberlândia, v. 35, n. 2, p. 367-376, 2019. DOI: 10.14393/BJ-v35n2a2019-41747

MARCOS FILHO, J. Fisiologia de sementes de plantas cultivadas. 2. ed. Londrina: ABRATES, 2015b. v. 1, 659 p.

MARCOS FILHO, J. Seed vigor testing: an overview of the past, present and future perspective. Scientia Agricola, Piracicaba, v. 72, n. 4, p. 363-374, 2015a. DOI: 10.1590/0103-9016-2015-0007

MAGUIRE, J. D. Speed of germination: aid in selection and evaluation for seedling emergence and vigour. Crop Science, v. 2, n. 1, p. 176-177, 1962. DOI: $10.2135 /$ crops ci1962.0011183x000200020033x

McDONALD, M. B.; PHANEENDRANATH, B. R. A modified accelerated aging seed vigor test for soybeans. Journal of Seed Technology, Lensing, v. 3, n. 1, p. 27-37, 1978. 
MELO, P. A. F. R.; JEROMINI, T. S.; AFFONSO, C. E.; ALVES, E. U.; MARTINS, C. C. Vigor tests in assessing the quality of signal grass seeds. Semina: Ciencias Agrárias, Londrina, v. 38, n. 6, p. 3491-3498, 2017. DOI: 10.5433/1679-0359.2017v38n6p3491

NAKAGAWA, J. Testes de vigor baseados na avaliação das plântulas. In: VIEIRA, R. D.; CARVALHO, N. M. Testes de vigor em sementes. Jaboticabal: FUNEP, 1994. p. 49-85.

NASCIMENTO, W. M.; FREITAS, R. D.; GOMES, E. M. L. G.; SOARES, A. S. Metodologia para o teste de envelhecimento acelerado em sementes de ervilha. Horticultura Brasileira, Brasília, v. 25, n. 2, p. 205-209, 2007. DOI: $10.1590 / \mathrm{S} 0102-05362007000200015$

OLIVEIRA, S. S. C.; MARTINS, C. C.; CRUZ, S. J. S.; SILVA, C. J. Seleção de progênies de nabo-forrageiro para germinação sob altas temperaturas. Ciência Rural, Santa Maria, v. 44, n. 2, 2014. DOI: 10.1590/S010384782014000200004

PARIZ, C. M.; FERREIRA, R. L.; SÁ, M. E. D.; ANDREOTTI, M.; CHIODEROLI, C. A.; RIBEIRO, A. P. Qualidade fisiológica de sementes de Brachiaria e avaliação da produtividade de massa seca, em diferentes sistemas de integração lavoura-pecuária sob irrigação. Pesquisa Agropecuária Tropical, Goiânia, v. 40, n. 3, p. 330-340, 2010. DOI: 10.5216/pat.v40i3.6590

PINNOW, C.; BENIN, G.; VIOLA, R.; SILVA, C. D.; GUTKOSKI, L. C.; CASSOL, L. C. Qualidade industrial do trigo em resposta à adubação verde e doses de nitrogênio. Bragantia, Campinas, v. 72, n. 1, p. 20-28, 2013. DOI: $10.1590 / \mathrm{S} 0006-87052013005000019$

RAMOS, N. P.; FLOR, E. P. O.; MENDONÇA, E. A. F. D.; MINAMI, K. Envelhecimento acelerado em sementes de rúcula (Eruca sativa L.). Revista Brasileira de Sementes, Londrina, v. 26, n. 1, p. 98-103, 2004. DOI: 10.1590/S0101-31222004000100015
RODINO, A. P.; HERNÁNDEZ-NISTAL, J.; HERMIDA, M.; SANTALLA, M.; RON, A. M. Sources of variation for sustainable field pea breeding. Euphytica, Netherlands, v. 166, n. 1, p. 95-107, 2009. DOI: $10.1007 /$ s10681-008-9842-y

SANTOS, C. M. R.; MENEZES, N. D.; VILLELA, F. A. Alteração fisiológicas e bioquímicas em sementes de feijão envelhecidas artificialmente. Revista Brasileira de Sementes, Londrina, v. 26, n. 1, p. 110-119, 2004. DOI: 10.1590/S0101-31222004000100017

SILVA, G. Z.; MARTINS, C. C.; CRUZ, J. O.; JEROMINI, T. S.; BRUNO, R. D. L. A. Evaluation the physiological quality of Brachiaria brizantha cv. BRS 'Piatã' seeds. Bioscience Journal, Uberlândia, v. 33, n. 3, p. 572-580, 2017. DOI: 10.14393/BJ-v33n3-36519

SOUZA, S. A.; NAGAKAWA, J. MACHADO, C. G. Teste de envelhecimento acelerado em sementes de aveia preta. Revista Brasileira de Sementes, Londrina, v. 31 , n. 2 , p. $155-163,2009$. DOI: 10.1590/S010131222009000200018

TAN, M.; KIRCI, K. K.; GUL, Z. D. Effects of Row Spacing and Seeding Rate on Hay and Seed Yield of Eastern Anatolian Forage Pea (Pisum sativum ssp. arvense L.) Ecotype. Turkish Journal of Field Crops, Turkey, v. 19, n. 1, p. 96-100, 2014. DOI: 10.17557/ tjfc. 47786

TOMM, G. O.; GIORDANO, L. de B.; SANTOS, H. P. dos; VOSS, M.; NASCIMENTO, W. M. N.; ÁLVARES, M. do C. Ervilha BRS Forrageira: uma nova alternativa para cobertura de solo. Passo Fundo: Embrapa TrigoFôlder/Folheto/Cartilha (INFOTECA-E), 2002.

VIEIRA, R. D.; KRZYZANOWSKI, F. C. Teste de condutividade elétrica. In: KRZYZANOWSKI, F. C.; VIEIRA, R. D.; FRANÇA NETO, J. B. (Ed.). Vigor de sementes: conceitos e testes. Londrina: ABRATES, 1999. cap. 4. p. 1-26. 